\title{
Mind the gap: suggestions for bridging the divide between formal and informal social security
}

\author{
ANDRIETTE HENDRINA DEKKER \\ Professor, Department of Mercantile Law, UNISA
}

\section{INTRODUCTION}

Social security is not only necessary to achieve social justice; it is also an indispensable tool in the fight against poverty. Social security refers to protective measures which are designed to guarantee everyone a certain degree of security, normally in the event of loss of income. This usually happens as a result of a certain calamity such as illness, injury or old age. ${ }^{1}$ The South African social security system consists mainly of social insurance ${ }^{2}$ and social

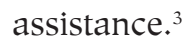

As a result of the impact of Apartheid on the social security system, one of the biggest shortcomings of the present South African system relates to the fact that it does not provide comprehensive coverage. Social security is

1 Olivier MP, Kalula E, Van Steenberge J, Jorens Y \& Van Eeckhoutte W The extension of social security protection in South Africa, SiberInk (2001) 9.

2 Social insurance is financed by contributions which are normally shared among employers, employees and, sometimes, the state. These schemes provide for the automatic payment of benefits and the rendering of services whenever the social risk against which the beneficiaries insure themselves occurs. Participation is normally compulsory. Contributions are accumulated in special funds from which benefits are paid. Surplus funds are invested to earn further income. A person's right to a benefit is secured by his/her contribution record, without any needs or means test. Contribution and benefit rates are often related to what a person is, or has been, earning. The South African social insurance system comprises the following important components: unemployment insurance, pensions, health care, occupational injuries and diseases. International Labour Organisation (ILO) "Introduction to Social Security" (3rd ed), International Labour Organisation (1984) 4.

3 In the case of social assistance, a beneficiary receives benefits and/or services that are wholly funded and supported by the state. These benefits and/or services are means-tested and are provided whenever, and for as long as, the beneficiary are in need of assistance. Social assistance benefits are non-contributory and can assist people who must rely on their own social security strategies (e.g. informal social security) for survival. There is a legal right to the payment of benefits, which are paid in the prescribed categories of need, for example old people and people with disabilities. Social assistance is designed to bring a person's total income up to a community-determined minimum. The South African social assistance system comprises the following important components: social assistance grants, i.e. older person's grant, disability grant, child grants, as well as financial awards to individuals for the social relief of distress, special pensions, military pensions, gratuities and financial reparation for individuals who have suffered because of political confrontation, financial awards to welfare organisations, state-sponsored provision of social services, facilities and programmes. Idem at 5 . 
only provided to certain categories of people; for certain risks and it can only provide low levels of benefits. ${ }^{4}$

An interesting result of the exclusionary nature of the formal social security system is that, for a long time, people who were excluded from social security had no alternative other than to devise social security mechanisms outside of the state-regulated system. These alternative forms can be termed informal social security. Although informal social security provides a certain degree of security, it functions outside the protection and recognition of the formal system.

Just more than a decade ago, South Africa incepted its new Constitution ${ }^{5}$ and begun its first steps on the road of true democracy. For the first time in the history of the country, was the right of access to social security recognised as a fundamental right. In terms of section 27 of the Constitution everyone has the right to have access to social security and appropriate social assistance. The state must respect, protect, promote and fulfil these rights and should thus take reasonable legislative and other measures within its available resources to achieve their progressive realisation.

The exclusivity of the present system has forced Government to attempt reforming the formal system, especially in light of the compelling contents of section 27 of the Constitution. Despite the fact that the State has achieved some important milestones by way of reform, ${ }^{6}$ the system still does not provide comprehensive coverage.

It is believed that informal social security can help Government to provide increased and more comprehensive formal social security. This article contains suggestions for mechanisms to enhance the increased cooperation between these two social security systems that can assist Government to provide improved and more comprehensive social security.

4 Although the State is the main role-player in social security an interesting feature of the South African social security system is that private role-players are also involved. This is known as the public-private divide of the South African social security system. For example if you take a risk such as older person's grant protection, there is a grant for the elderly in the form of an old-age grant (eligibility criteria) which is a form of social assistance and is provided by the State. There is also a form of social insurance available in the form of private provident and pension funds which is available for private individuals to join. Olivier MP, Okpaluba MC, Smit N Thompson M "Social security law: general principles" (1st ed), Butterworths (1999) 3-4.

5 Constitution of the Republic of South Africa, 1996.

6 Some of the important milestones are for example, the publication of the White Paper for Social Welfare GN 1108 (GG 18166 of 8 August 1997), Report of the Ministerial Committee on Abuse, Neglect and Ill-Treatment of Older Persons "Mothers and Fathers of the Nation: The Forgotten People?", Pretoria February 2001; the appointment of the Committee of Inquiry into a Comprehensive System of Social Security for South Africa and their resultant report Transforming the Present - Protecting the Future (Draft Consolidated Report) March 2002 (hereafter Taylor Report); the Social Security Agency Act 9 of 2004, the Social Assistance Act 13 of 2004 (although not yet in operation); increasing the eligibility ages so that all children under the age of 14 years can qualify for the child support grant and men older than 63 years of age can qualify for the old age grant; social assistance benefits have been made available to permanent residents after the Constitutional Court decision of Khosa and others $v$ The Minister of Social Development and others; Mahlaule and others $v$ The Minister of Social Development and others 2004 (6) BCLR 569 (CC) at para 46-7. 


\section{INFORMAL SOCIAL SECURITY}

Informal social security is a particular form of social security provided by family and/or community members which can be compared to the benefits which one would normally obtain from as a result of formal social security. One of the important characteristics of informal social security is the fact that it is characterised by a support network based on a strong sense of solidarity and on the premise of reciprocity and ubuntu. ${ }^{7}$

Informal social security can be divided into two main categories, namely kinship-based and neighbourhood-based social security. The former relates to social protection provided to blood relatives and the latter refers to mutual aid schemes that have developed among people within a specific community. The former normally comprises support or monetary transfers provided by and for family members, whereas the latter refers to support and monetary transfers provided by communities, normally along the lines of one or other common denominator, for example traders in the same neighbourhood.

It is problematic and impossible to attempt a clear distinction between the two forms of informal social security, since they often co-exist and overlap, in addition to co-existing and overlapping with other formal forms of social security. ${ }^{8}$

Despite the important purpose fulfilled by informal social security, it must be appreciated that informal social security is subject to limitation. The extended family structure is weakened for example by urbanisation and HIV/ AIDS. In addition, it functions in a poor environment resulting in inadequate benefits which are often uncertain, especially during widespread or prolonged crises. ${ }^{9}$

Currently, informal and formal social security exist as two separate social security networks. International organisations and writers have begun to realise the importance of informal social security as a way in which to extend social security to people excluded from such formal protection. The ultimate goal to which the social security system should aspire is comprehensive social protection. Informal social security can be utilised as a means to achieve this goal.

7 Samson M et al Social Security Reform and the Basic Income Grant for South Africa Economic Policy Research Institute Policy Report 31 (2002) at 1. Also see Olivier et al (fn 4 above) 14.

8 Informal and formal social security systems often co-exist. Many families base their means of support and survival strategies on neighbourhood-based, kinship-based and formal social assistance (where a member of the family receives a disability or old-age grant). In South Africa, for example, the old-age grant (which is the largest social assistance programme) is, in most instances, the only form of income for families, which often comprise three generations. See Taylor Report (fn 6 above) 59 .

9 Chen MA, Jhabvala R, Lund F "Supporting Workers in the Informal Economy: A Policy Framework" Working Paper on the Informal Economy prepared for the International Labor Organisation (Employment Sector) (2002/2) 41. 


\section{MECHANISMS WHICH CAN BE USED TO INTEGRATE INFORMAL SOCIAL SECURITY INTO THE PRESENT SOCIAL SECURITY FRAMEWORK}

Formal and informal social security in South Africa can be described as traveling on parallel roads. The formal social security system is on a single, tarred carriage-way. This road is in the process of being improved and is being transformed into a dual carriage-way. Informal social security is traveling on a road parallel to this road, and to the same destination, but its road is only a small dirt road with potholes. Since both roads lead to the same destination, and run along more or less the same course, it is time to consider whether they should not both form part of the greater road-planning project for the area. Below are some of the mechanisms suggested to ensure that these two roads are both utilised to help more people reach the final destination of comprehensive social security.

\subsection{The role of government}

The state bears the ultimate responsibility for ensuring the realisation of social security rights ${ }^{10}$ because of its authority and its resources for promoting social security for all, and, in South Africa, because of its constitutional obligation. ${ }^{11}$

The role of government is critical in order for informal social security schemes to be improved. Government can undertake this process in partnership with other groups. Multi-actor involvement is crucial to ensure comprehensive social security. ${ }^{12}$

Given the fact that the field of social security is affected by a number of different state policies, only the government itself can possibly change and integrate cross-sectoral policies in a structured and coherent manner. Governments can create policies which will strengthen informal obligations to provide support. State policies should endeavour as far as possible to maintain or improve the capacity of informal social security mechanisms.

The starting point in efforts to strengthen informal social security systems is government recognition of and support for the fact that informal social

10 Olivier MP, Mpedi LG "Extending Social Security Protection to Families in the African Context: The Complementary Role of Formal and Informal Social Security" Paper presented at the 4th International Research Conference of the International Social Security Association Social Security in a Long-Life Society (Antwerp, Belgium 5-7 May 2003) 33.

11 Von Benda-Beckmann F, Kirsch R, Freiburg-Strauß J "Report on the Regional Seminar on the Capacity of Social Security Systems in Southern Africa: Conditions, Constellations an Socio-Political Relevance" Volume 1 (September 11-15, 1995) Eschborn: GT Z (1997) 55-56 \& 59.

12 The need for multi-actor responsibility in the process of realising socio-economic rights has been highlighted in Government of the Republic of South Africa and others $v$ Grootboom and others (2000) (11) BCLR 1169 (CC) at para 39. The Constitutional Court found that "the right to have access to" a particular socio-economic right means that the State must enable other role players, through legislation and other measures, to provide access to socio-economic rights (pars $24 \& 25$ ). 
security systems are providing social security for a large number of people. There are four possible forms of government support: ${ }^{13}$

- The role of facilitator and promoter. The state can promote informal social security schemes through recommendations concerning design and good practice (e.g. in relation to the benefit package, affiliation and administration), through the introduction of management information systems and programmes to improve managerial procedures, through providing assistance as regards more secure investments, and through assistance in recruiting more members.

- Government can also encourage the broadening of the protective scope of informal social security systems and introduce linkages with existing formal social security schemes. Scope should be created for strategy development so that schemes can grow over time.

- The state can also fulfil a monitoring function. Informal social security schemes must be adequately monitored and evaluated. For example, the state can monitor the performance of informal social security schemes within the context of legislation providing for the efficient and transparent administration of schemes. Government can also ensure that schemes have the necessary legal status to function as official entities.

- The state can act as co-financier to ensure access to informal social security. This can take the form of subsidies or matching contributions.

The State should not attempt to control or over-regulate informal social security schemes. The participation of these groups in social security will be enhanced by avoiding over-bureaucratisation and by fostering participation and democratic decision-making. ${ }^{14}$

In addition to linking formal and informal social security, government also needs to adopt policies and programmes that address the basic social and economic needs of citizens. There is little point in attempting to enhance the effectiveness of the social security system if broader social and economic policies exacerbate the conditions of poverty and deprivation that exist in the country. ${ }^{15}$

\subsection{Continued and improved social assistance}

The importance of the social assistance system is widely recognised. ${ }^{16}$ It is recommended that the benefits currently available in terms of social assist-

13 Kaseke E "Informal Social Security in Eastern and Southern Africa" Paper presented at Centre for comparative labour and social security law (CICLASS) \& SADC (Southern African Development Community) Social Security Conference, Johannesburg, (17-19 October 2001) 8.

14 Midgley J, Sherraden M (eds) Alternatives to social security: an international inquiry 1st, Auburn House (1997) 114.

15 The above proposals link up with the new strategy recommended by the International Labour Organisation for improving and extending social security coverage. Reynaud E "The Extension of Social Security Coverage: The Approach of the International Labour Organisation Extension of Social Security", Paper No. 3 Social Security Policy and Development Branch, International Labour Organisation (2002) 1.

16 "The important redistributive impact of this (social assistance) programme has been recognised by Government, labour and academia” Taylor Report (fn 6 above) 58. 
ance should be increased. In the past few years, increases in grants have been above the inflation rate, and this precedent should be continued. ${ }^{17}$

Since the aim of this article is not to discuss the shortcomings and possible reforms of the formal social security system in detail, it will suffice to suggest that where possible, reform in line with the recommendations of the Taylor Committee should take place. The Taylor Committee recommended that a more comprehensive social assistance system, which can play an important role in achieving medium- to long-term economic transformation in the country, must be developed. In addition to the present grants available, the Committee also found that a Basic Income Grant (BIG) will be able to eliminate destitution and as a long-term intervention, the Committee recommended the creation of a new grant to adults living in destitution and poverty. ${ }^{18}$

It is also important to realise that, as long as the social assistance system does not function properly, it will (unnecessarily) increase the pressure on the informal social security system. ${ }^{19}$ It is therefore proposed that the formal social assistance system should also continue to improve its service delivery and administrative capacities. This will directly impact on the informal social security system by relieving the unnecessary burden on the system as a result of those eligible for social assistance being denied benefits and consequently having to rely on the informal social security system for support. ${ }^{20}$

\subsection{Expanding the social insurance system}

Experience in a number of countries has shown that the extension of formal social insurance is feasible. However, the extension of social insurance to the informal sector remains problematic. This is mainly because of the serious problems encountered in identifying, registering, educating, persuading and monitoring persons and businesses in the informal economy to ensure that they comply with all the rules of the scheme. Even where compulsory social insurance schemes are extended to informal workers, these schemes may not be successful if the benefit and contribution structures of the schemes are not appropriate for the various categories of informal workers. ${ }^{21}$

Workers in the informal economy are often excluded from formal social security schemes not only because of the formal-employment bias of the system, but also because of the fact that they are often unwilling, or unable, to contribute a relatively high percentage of their income in order to finance

17 Currently 12.5 million out of 48 million citizens benefited from direct support form grant. Cost to country is $3,4 \%$ of the GDP. Obtained from keynote address by Minister of Social Development, Dr ZST Skweyiya to the International Social Security Conference, Cape Town, 10-15 March 2008 accessed at http://www.dsd.gov.za/dynamic/dynamic.aspx?pageid=4618id=983 on 25 March 2008.

18 Taylor Report (fn 6 above) 65-66.

19 See Khosa judgment (fn 6 above) at paras 46-7.

20 Since 1 April 2006 social security provisioning has been made the competency of the South African Social Security Agency (SASSA). It seems there was an improvement in service delivery since then.

21 International Labour Organisation (ILO) "Decent Work and the Informal Economy", (Report IV) (2002) 59. 
social security benefits that do not meet their priority needs. They give greater priority to their immediate needs, such as health and education. ${ }^{22}$

Despite these challenges it is estimated that the extension and reform of the formal social insurance system could reach about another 5 to 10 percent of the working population. ${ }^{23}$

\subsubsection{To cover a larger group of people}

The underlying assumption of the traditional International Labour Organisation (ILO) model of social security is that the number of people relying on informal social security will decrease as more people are absorbed into formal employment.

The formal South African social security system can, however, to a limited extent expand its current protective scope to include more people. This is also in line with the recommendations of the Taylor Committee.

"Further the Committee proposes that the principle of social insurance, based on entitlements through contributory schemes, should where feasible, be extended to include as many of the employed as possible. There are likely to be certain groups of workers who will remain excluded from social insurance schemes such as the UIF, because of their location in the workforce. For these workers other arrangements for providing social security are proposed." ${ }^{24}$

This was for example successfully done by also including domestic workers and high-income earners as "contributors" ("employees") for purposes of the Unemployment Insurance Act.

Other possible extensions which can still be made to the formal social insurance system to make it more representative are the following:

\subsubsection{Unemployment insurance}

- For purposes of the Unemployment Insurance Act, the Taylor Committee recommended that access to maternity-type benefits for those in casual, seasonal or insecure employment should be investigated. ${ }^{25}$

- Government employees should be allowed to become contributors to the UIF. $^{26}$

22 Van Ginneken W “Extending Social Security: Policies for Developing Countries” (2003) 142 International Labour Review 275 at 278.

23 Olivier et al (fn 4 above) 9-13.

24 Taylor Report (fn 6 above) 71.

25 Idem at 72.

26 Olivier MP, Van Kerken E "Unemployment Insurance" in Olivier MP, Smit N, Kalula ER, Mhone GCZ Introduction to Social Security (1st ed), Butterworths (1993) at 439-442 argue that the continued exclusion of public servants from the UIF creates a specific category of vulnerability. From an international perspective, the various ILO Conventions and Recommendations are clearly aimed at inclusion of public servants in unemployment insurance schemes. For example Convention 168 of 1998 concerning Employment Promotion and Protection against Unemployment provides that such a scheme should cover not less than 85 percent of all employees, including public servants. 


\subsubsection{Retirement provisioning}

- All people in the formal sector (including all casual and part-time employees) must be required to contribute a minimum percentage of their income for retirement savings according to the Taylor Committee. ${ }^{27}$

- The Committee further recommended that survivor's and disability cover be mandated as one of the benefits provided by retirement funds. ${ }^{28}$

\subsubsection{Occupational injuries and diseases}

The Taylor Committee recommended that domestic workers, the self-employed and independent contractors should be included under the protective scope of the Act, as their exclusion presently violates the right to equal protection and benefit of the law guaranteed in terms of section 9 of the Constitution. The preference accorded to civil law wives at the expense of indigenous law wives, wives according to custom and a cohabitant should end, as this is also subject to challenge in terms of the Constitution. The possibility of voluntary registration in terms of COIDA should also be considered if compulsory coverage is not feasible. ${ }^{29}$

\subsubsection{To cover a broader range of risks}

The present risk-based approach of social security has been copied from the traditional ILO model of social security. This traditional approach is however not entirely appropriate for a developing country such as South Africa.

An overhaul in this regard will however not necessarily relate to the extension of risks, but to a move away from a risk-based approach towards a model of comprehensive social protection, as was suggested by the Taylor Committee. Comprehensive social protection aims to provide everyone with an adequate standard of living instead of providing protection against the occurrence of certain risks. ${ }^{30}$ At the recent International Social Security Conference held by the Department of Social Development, the Minister of Social Development referred to this approach as "Dynamic Social Security": 31

"Such an approach calls for sustainable and accessible social security systems that are based on integrated, proactive and innovative responses to help manage the risks and realise the opportunities that economic globalisation could offer. Of course in broadening the concept of social security, we add new dimensions to the tasks of social security institutions, but this should ensure that social security remains a positive force in the development of societies and individuals. In the context of Africa, the most important challenge for social security remains the extension of coverage. Given our place on the economic world stage, our social security approach needs to place greater emphasis on poverty reduction and social inclusion.”

27 Taylor Report (fn 6 above) 94.

28 Idem at 95.

29 Idem at 114

30 See Grootboom (fn 12 above) and also Minister of Health $v$ Treatment Action Campaign and others 2002 (10) BCLR 1033 (CC).

31 Skweyiya (fn 17 above) 6. 
Adoption of a broader concept of and approach to social security will not necessarily provide immediate and greater protection to people in need, but it will lay the foundation for the extension of policy to address social exclusion.

\subsection{Legislative changes}

Although it is feared that regulation would weaken rather than strengthen informal social security, a certain degree of regulation is necessary to improve the functioning of these schemes. ${ }^{32}$ An appropriate legal framework will also simplify future cooperation between the existing formal and informal social security systems in the country. ${ }^{33}$

If legislation is developed for informal social security schemes, it needs to be sensitive to the following three points: ${ }^{34}$

- Formalities need to be simple; many people who are excluded from formal social security are often also illiterate. Even for those who can read and write it is often difficult to complete a form, since particulars such as fixed address and date of birth are unknown and vary.

- Social security systems have to be affordable. There should also be confidence that one will receive a return on the premiums paid. Costs that are justified are often seen as affordable. Also important are the time and method of payment, for a certain degree of flexibility is necessary, although everyone must comply with the same rules..$^{35}$

- The close proximity of service centres to residences of potential members is important, since access to transport is often not readily available and, if available, is expensive.

\subsection{Strengthening informal social security systems}

The continued existence of informal social security schemes can be ensured by strengthening them through the development of linkages between formal and informal social security mechanisms and by improving their functioning.

Linkages with the formal social security schemes can enable informal social security schemes to improve their risk management strategies, most importantly prevention strategies, but also risk mitigation and coping strategies. ${ }^{36}$

32 Maes A "Informal Economic and Social Security in Sub-Saharan Africa" (Jul-Dec 2003) 56 International Social Security Review (ISSR) 50 at 53.

33 Midgley, Sherraden (fn 14 above) 115.

34 Maes (fn 32 above) 53-54.

35 For example, one option would be to provide for payment in kind or to allow some form of labour as payment, for example where people from the local community work in an administrative capacity for an informal social security scheme.

36 Olivier MP, Kaseke E \& Mpedi G "Formulating an integrated social security response - perspectives on developing links between informal and formal social security in the SADC region" Paper presented at Expert Group on Development Issues (EGDI) and United Nations University World Institute for Development Economics Research (UNU-WIDER) Conference Unlocking human potential: linking the informal and formal sectors, 17-18 Sept 2004, Helsinki, Finland 15-16. 
Governments and private role players should become involved in informal social security arrangements by means of training and skills development. Training can also help to strengthen the administrative capacity of informal social security schemes, especially as far as compliance, record-keeping and financial management are concerned. ${ }^{37}$ This can go hand in hand with education and public awareness programmes to improve the image of the social security system. ${ }^{38}$

Ancillary measures to support informal social security schemes could be to provide better access to financial institutions and support. In this regard, nongovernmental role players (such as the banking sector) can play an important supportive role. Better access to financial institutions can go hand in hand with training regarding better financial practices, investment strategies and basic book-keeping.

A more compelling step could be to promote registration of informal social security schemes. There is currently very little or no legislation regulating informal social security schemes. One of the only acts which will apply in this context is the Friendly Societies Act 25 of 1956. Although the definition of a friendly society in terms of the act is wide enough to include certain informal social insurance arrangements such as burial societies and stokvels, the scope of application of the Act is restricted to friendly societies whose aggregate value of income does not exceed R100 000 per annum..$^{39}$ It would seem that this provision precludes many informal social security schemes from registering.

Registration will enable the government to better monitor the extent and activities of informal social security schemes. Registered schemes could gradually be encouraged to improve their accountability and administrative and financial practices. This basic network could also gradually be encouraged to expand the present risks which it covers, or to expand its membership base to cover more people who do not belong to modern social insurance schemes. For example, if a registered, informal social security scheme complies with certain minimum requirements, it could qualify for a government subsidy, provided that it covers a compulsory risk such as health care. If registration is encouraged, the process should be simplified.

This process should be tackled with the best interests of the informal social security schemes in mind, and not at their expense. Olivier \& Mpedi suggests the following valuable preconditions to guide this process: ${ }^{40}$

- Informal social security does not replace the state's responsibility to provide social security protection.

- Linking and integrating informal and formal social security schemes should serve the purpose of extending coverage and a minimum level of protection.

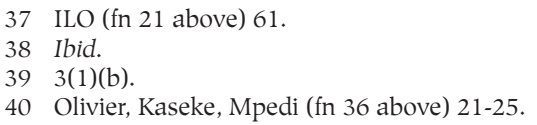


- Informal social security schemes and their users should be protected against abuse from the state and other stakeholders.

- Linking and integration should result in gradual evolvement and preservation of the core values of informal social security schemes.

- It should be realised that not all informal social security schemes are amendable to integration.

\subsection{Create innovative schemes which combine formal and informal social security}

Where communities are willing to help themselves, the State should step up to the plate and help them to help themselves. This will result in state and community working together to create unique social security schemes.

If one looks at examples of the ILO and other countries who attempted to devise and implement such schemes, the most popular type of scheme where formal and informal social security is combined is for example mutual health insurance schemes. Mutual health insurance refers to informal social insurance schemes where communities finance health insurance schemes in order to allow them access to the necessary health care and to provide some protection against the cost of illness. In return the State provides certain lowcost health care services to these communities. The community participates in running the scheme, but the government or social insurance system contributes a significant amount to the financing. ${ }^{41}$

In the design of new schemes, such as mutual health insurance schemes, two principles should however be kept in mind, namely:

- The type of risk to be addressed. Only certain risks are appropriate for protection by small-scale schemes. For example, protection against old age is a covariate risk and a small-scale scheme will be able to provide long-term protection.

- The level of intervention by the government and the informal social security system respectively. The state can be involved in its capacity as financier, administrator or delivery agent.

It is recommended that, in the development of new schemes, the focus should be on small-scale feasibility studies and gradual implementation. The work of the International Labour Organisation (ILO) in other developing countries could provide useful guidelines in this regard. Government could initiate pilot projects to ascertain the possibility of creating special social security schemes for people currently excluded from social security.

41 Jütting J "Public-Private Partnerships in the Health Sector: Experiences from Developing Countries" International Labour Organisation Working Paper: Extension of Social Security (2002) 2-3. 


\subsection{Cooperation between existing informal social security schemes}

Existing informal social security schemes are potentially valuable resources. Those which have well-defined social security functions and which are already properly constituted can be encouraged to expand their activities to cover many more people who do not belong to formal social insurance schemes. Informal and loosely organised societies can be helped to consolidate their activities and to provide a more effective service. Those cooperative societies which do not have any social security responsibilities can be encouraged to extend their activities into this field and be given the necessary assistance to develop the appropriate skills and services. ${ }^{42}$

Informal and loosely organised societies should be assisted to consolidate their activities in order to provide a more effective service. Through partnerships, informal social security schemes can acquire greater negotiation power, can share knowledge and can ensure greater financial stability. This process could be initiated by providing a forum in which schemes are able to discuss relevant matters and establish possible common ground and areas for linking up. Public awareness programmes can be used to raise awareness of the role played by informal social security measures. This could help to get more people to voluntarily join informal social security schemes, thereby increasing their risk pool and ensuring their continued existence.

The coverage of informal social security schemes can also be improved through partnerships such as organisations formed by these schemes among themselves. This will enable these schemes to; for example, acquire stronger negotiation power, to increase the sharing of knowledge and to achieve greater financial stability. ${ }^{43}$

\subsection{Research}

Before policies can be formulated, more research is needed into the activities of informal social security schemes so as to identify the reasons for their existence, their role and nature and the constraints and problems they encounter. ${ }^{44}$

National governments can be assisted by international agencies such as the International Social Security Association (ISSA) and the International Labour Organisation (ILO). These agencies can encourage research into the field of informal social security and can make money available to foster the development of appropriate social security programmes.

\footnotetext{
42 Midgley J Social Security, Equality and the Third World 1st, Wiley (1984) 203-205. This can for example be achieved by encouraging existing agricultural, marketing and consumer societies to establish social security schemes for their members.

43 Van Ginneken (fn 22 above) 283.

44 Olivier, Kaseke, Mpedi (fn 36 above) 16.
} 
New approaches to social security require much more detailed insight into the complex interrelations between the different elements of the totality of social security regulations, institutions and practices. ${ }^{45}$

More effort must be devoted to the marketing of informal social security, as a large percentage of the target population may still not be well informed of the benefits of being insured. ${ }^{46}$

\section{CONCLUSION}

South Africa embarked on a very challenging and exciting road in 1993. One of the areas affected by the new road taken since then is social security. With the dawn of democracy, the social security system was, and still is, in dire need of change. The history of the country led to a system of co-existence between formal and informal social security. The latter was however largely ignored by policy and regulation. With the introduction of the new Constitution, the right of access to social security was entrenched as a fundamental right. Many changes to the present social security system have been made, but these were mostly ad hoc and lacked a comprehensive approach. Although informal social security has, since then, increasingly been recognised as part of the social security landscape in all the proposals for reform, the full potential of informal social security has not been explored.

One of the biggest challenges for the present government is poverty alleviation, and social security is one of the most important tools for addressing this issue.

"The extension of coverage to the informal sector and to the poor in remote rural areas is a particularly challenging task we face. In Africa, this presents one of the biggest challenges we must address if we want to make any dent on poverty. We cannot avoid issues of the need to improve the performance of our economies, so that we can improve affordability even as we deal with the more immediate challenge to develop innovative approaches to collect contributions.....We must find ways to close the gap between social security provision for those in the formal and those in the informal sector." 47

It is clear that government is increasingly realising the need to look at new avenues to ensure greater inclusivity of the social security system. It is hoped that the possibilities presented by informal social security are also explored as new ways in which to widen the social security net.

Informal social security can play a major role in realising the goal of increased social security. The mechanisms proposed in this article will, it is hoped, serve as a baseline for stimulating debate and generating new innovative ideas as to how to improve the social security system in South Africa.

\footnotetext{
45 Von Benda-Beckmann et al (fn 11 above) at 56.

46 Idem at 64.

47 Skweyiya (fn 17 above) 7.
} 


\section{BIBLIOGRAPHY}

Chen MA, Jhabvala $\mathrm{R}$ \& Lund F "Supporting Workers in the Informal Economy: A Policy Framework” Working Paper on the Informal Economy prepared for the ILO (Employment Sector) (2002/2).

Committee of Inquiry into a Comprehensive System of Social Security for South Africa and their resultant report "Transforming the Present - Protecting the Future (Draft Consolidated Report)" March 2002.

Government of the Republic of South Africa and others $v$ Grootboom and others 200011 BCLR 1169 (CC).

International Labour Organisation (ILO) "Decent Work and the Informal Economy" (Report IV) (2002).

International Labour Organisation (ILO) "Introduction to Social Security" 3rd ed, International Labour Organisation (1984).

Jütting J "Public-Private Partnerships in the Health Sector: Experiences from Developing Countries" International Labour Organisation Working Paper: Extension of Social Security (2002).

Kaseke E "Informal Social Security in Eastern and Southern Africa” Paper presented at Centre for comparative labour and social security law (CICLASS) \& SADC (Southern African Development Community) Social Security Conference, Johannesburg, 17-19 October 2001.

Khosa and others $v$ The Minister of Social Development and others; Mahlaule and others $v$ The Minister of Social Development and others 2004 (6) BCLR 569 (CC).

Maes A "Informal Economic and Social Security in Sub-Saharan Africa” (JulDec 2003) 56 International Social Security Review (ISSR) 50.

Midgley J Social Security, Equality and the Third World 1st, Wiley (1984).

Midgley J \& Sherraden M (eds) Alternatives to social security: an international inquiry 1st, Auburn House (1997).

Minister of Health $v$ Treatment Action Campaign and others 2002 (10) BCLR 1033 (CC).

Olivier MP, Kalula E, Van Steenberge J, Jorens Y \& Van Eeckhoutte W (eds) The extension of social security protection in South Africa 1st ed, SiberInk (2001).

Olivier MP, Kaseke E \& Mpedi G "Formulating an integrated social security response - perspectives on developing links between informal and formal social security in the SADC region" Paper presented at Expert Group on Development Issues (EGDI) and United Nations University World Institute for Development Economics Research (UNU-WIDER) Conference Unlocking human potential: linking the informal and formal sectors, 17-18 Sept 2004, Helsinki, Finland.

Olivier MP \& Mpedi LG "Extending Social Security Protection to Families in the African Context: The Complementary Role of Formal and Informal Social Security" Paper presented at the 4th International Research Confer- 
ence of the International Social Security Association Social Security in a Long-Life Society (Antwerp, Belgium 5-7 May 2003).

Olivier MP, Okpaluba MC, Smit N \& Thompson M Social security law: general principles 1st ed, Butterworths (1999).

Olivier MP \& Van Kerken E "Unemployment Insurance" in Olivier MP, Smit N, Kalula ER \& Mhone GCZ Introduction to Social Security 1st ed, Butterworths (1993)

Reynaud E "The Extension of Social Security Coverage: The Approach of the ILO” Extension of Social Security, Paper No. 3 Social Security Policy and Development Branch, ILO (2002).

Samson $M$ et al "Social Security Reform and the Basic Income Grant for South Africa” Economic Policy Research Institute Policy Report 31 (2002).

Van Ginneken W "Extending Social Security: Policies for Developing Countries” (2003) 142 International Labour Review 275.

Von Benda-Beckmann F, Kirsch R \& Freiburg-Strau $\beta$ J "Report on the Regional Seminar on the Capacity of Social Security Systems in Southern Africa": Conditions, Constellations an Socio-Political Relevance Volume 1 (September 11-15, 1995) Eschborn: GTZ (1997). 